\title{
Stakeholder Analysis in Community Based Mangrove Management: Case of Forest Management Unit in Region 3 of Aceh Province
}

\author{
OK Hasnanda Syahputra ${ }^{1 *}$, Bramasto Nugroho ${ }^{2}$, Hariadi Kartodihardjo ${ }^{2}$ Nyoto Santoso ${ }^{3}$ \\ ${ }^{1}$ Graduate School of Bogor Agricultural University, Dramaga Campus, Bogor 16680, Indonesia \\ ${ }^{2}$ Department of Forest Management, Faculty of Forestry, Bogor Agricultural University, \\ ${ }^{3}$ Department of Forest Conservation, Faculty of Forestry, Bogor Agricultural University, \\ Dramaga Campus, Bogor 16680, Indonesiaa
}

Received July 3, 2018/Accepted December 23, 2018

\begin{abstract}
Mangrove under the management of Forest Management Unit (KPH) region 3 of Aceh Province is a forest area located in the eastern coastal area of Aceh Province and has great functions and benefits for the community. To find out how big and how many the stakeholders involved in mangrove management was, an analysis to identify and to map how great the interest-power, and ability to interact in the network was carried out. Stakeholders were identified from a selected interview with snowball sampling method. How stakeholders interact in a network describes the relationship among stakeholders and interacts with one another. The results showed that there were 26 stakeholders. With stakeholder mapping, they will ensure their position on the grid can be seen how much power they have and how much interest they have in it. Some actors such as Pusong Kapal Village community, Pusong Telaga Tujoh Village community, community forest, the village head, and community leaders have indicated how to manage through support mechanisms, and foster aspirations when formulating and designing stronger strategies. Thus the FMU can build and maintain long-term relationships that involve patterns of interaction especially with stakeholders who have a significant influence on the network.
\end{abstract}

Keywords: mangrove, stakeholders, network, forest management unit

*Correspondence author, email: okhasnanda2013@gmail.com, tel: +62-852-7008-6398

\section{Introduction}

The existence of Forest Management Unit (FMU) region 3 in Aceh Province is under the Decree of the Minister of Forestry No: 993/Menhut-II/2013 December 27, 2013. As an operational basis, Issuance of the Law on the Government of Aceh No. 20 Year 2013 concerns Organizational Structure and Working Procedure of Technical Service Provider At Aceh Forestry Service, with the mangrove area estimated to range $\pm 20,481$ ha. One of the problems is how to harmonize and involve various stakeholders in FMU development. Where stakeholders can have a strong position in determining the outcome of a political process, especially if it influences policy. Stakeholder participation is a medium to achieve objectives in carrying out activities. Through this participation, an action plan can be formulated and simultaneously implement these actions together.

On the one hand, the presence of FMU could play a role as a forest management organizer at a site level which should ensure that forest management was carried out sustainably in accordance with its function (Kartodihardjo et al. 2011). Meanwhile, the management of mangrove resources by the community proved to had benefit due to livelihood guarantee, access to resources, conflict resolution mechanism and sustainability orientation (Soontornwong 2006). Many research results suggested that local informal institution should be officially recognized in local forest management (Yami et al. 2011)

Stakeholder analysis could be used to identify all parties involved in mangrove management in FMU region 3, which can create or implement policies, and various intermediary parties between the two parties. Hence this analysis was helpful for knowing which actors were influential or were influenced when making decisions (Reed et al. 2009). Furthermore, the analysis would be beneficial for the impact on the policy could be maximized. Afterward, it could be used as an instrument to consider who needs to know the outcome and what their position and interests were. In this way, this analysis became an important instrument to estimate various interest groups around policy issues, and the group ability to influence the outcome.

This study was presented to identify and to map stakeholders in the community-based mangrove management institute at FMU region 3 of Aceh Province and to examine the constructed networks of various interlinked stakeholders, to deliver message or information so as it could be beneficial for them, how to maintain relationships with them, who would make contact and how to follow it up. This relationship primarily focused on the actors, nodes, and relationships used to describe the results of network analysis effectively (Saz-Carranza and Ospina 2010). 
The importance of stakeholder analysis in mangrove management The term stakeholder is often used to describe a community or organization that is affected by activity or policy, in which a party does not always receive a good impact. Some parties may bear the costs, and some will benefit from an activity or policy (Race and Millar 2008).

Stakeholder management concept is how to manage the parties effectively to realize their strategic objectives. Some dynamics occur in relation to the relationship among the parties in expressing responses and responses to ensure the robustness of the strategy with regard to organizational goals so that stakeholders who support or oppose and potentially disrupt the future of the organization can be recognized. This is characterized by the complexity of different and often conflicting stakeholder objectives. With this understanding, it will be possible to take strategic action in the form of providing support in building a power base by encouraging coalition formation or stopping stakeholders who tend to undermine stability by neutralizing their power. Thus stakeholder analysis can be applied to reveal the interests and influence (role) of the stakeholders (Muntasib 2014). Stakeholder analysis is also seen as an approach that can empower stakeholders to influence the decision-making process (Reed et al. 2009) by involving stakeholders such as the community, community leaders, universities and others as part of management with the consideration to increase interest and encourage them in accordance with the objectives of the organization, that is, placing them in positions that have the power and influence to position itself as a determining force in the direction of the management strategy. Stakeholder analysis is used to understand the diverse interests of potentially conflicting stakeholders. Therefore, stakeholder analysis can assist in mobilizing local resources (Rastogi et al. 2010)

Social network of mangrove management Stakeholder analysis approach only lists the actors involved, writes attributes (self-attached information) and lists the roles of each actor.

To illustrate the informal interaction of relationships between actors and determine which actors are influential, using social network analysis (SNA) methods. According to Scott (2011), SNA is a set of methods used to investigate aspects of relationships in data structures. SNA understands the role of the actor in the context of how the actor relates and is connected to other key actors (Borgatti et al. 2013; Kadushin 2012), emphasizing functional entities (roles), and the way in which entities are connected (Stanton et al. 2012) relates to the strength of bonding between different actors in the network (Crossley 2010), this concept explains what is actually happening within the social networking structure (Crossley 2010; Hollstein 2011). From this understanding, it can be said that SNA puts more emphasis on interaction among entities in it. Interaction patterns among entities will provide new information. It facilitates the exploration of the patterns and types of relationships among actors, in which these actors (perhaps individuals, groups or organizations) are visually represented in the network map by structural nodes and relationships (links or links) among the knots.

Several social networking studies have been conducted on social science at various levels of analysis to identify and describe the mechanisms that occur in social processes.
Brakke (2012) uses social networks to investigate social change mechanisms and change strategies to improve welfare, Henwood et al. (2015) investigates individual linked networks, while Barman-Adhikari et al. (2015) explores networks at the community level, and Bunger et al. (2014) examines inter-organizational network relationships.

\section{Methods}

This research was conducted in mangrove forest area in FMU 3 areas of Aceh Province, administratively located in Aceh Tamiang Regency, Langsa City and East Aceh Regency. Site selection consideration was done purposively (purposive sampling), that is, the location has a communitybased institution in mangrove management. Data collection in the field had been conducted for four months, from September 2015 s / d December 2015.

Data were collected by the snowballing method through interview, observation and document analysis (Bungin 2010). Interviews were conducted for key informants, heads of institutions/institutions as well as some key informants from the community. Then the interview following input from key informants was developed. Deepening is considered complete when there is saturation of information from key informants characterized by the repetition of the same information. Secondary data are the supporting data in this study obtained from various literature, reports, and other documents related to this research.

Stakeholders are identified by taking into account their position of interest and influence (Fletcher et al. 2003). Thus, stakeholders are grouped into groups, i.e. (i) key stakeholders are high stakeholders, but low impact rates, (ii) secondary stakeholders (intermediaries) are intermediaries in assisting the implementation process of moderate to low activity, (iii) key categories, with high levels of influence and importance.

Stakeholder analysis process (Reed et al. 2009) consists of 1) identifying, 2) grouping and categorizing, and 3) investigating the relationship. While to investigate the relationship that occurs, SNA was used. Mapping stakeholders by classifying the importance and influence of using interest-stake interest matrices. This matrix consists of four quadrants, where the stakeholder position in the quadrant represents the category of stakeholders in the community-based mangrove management agency in FMU 3 Aceh Province. Stakeholders were grouped into Key players, Context setters, subjects, and Crowd (Reed et al. 2009; Thompson 2011).

To investigate how stakeholder interactions relate to their positions and relationships within other stakeholder networks, it is important to analyze how the roles of the different actors and networks they build, in which some actors are systematically linked. Data analysis was done descriptively using social network analysis software (SNA) (Borgatti et al. 2002). With this method, it can be known which actors are the most influential and important in determining the success rate of mangrove management. Some patterns of connectedness in tissues (Borgatti et al. 2002):

1 The degree in the network is the number of connection to a node, or another actor is called Degree centrality. Degree centrality can be divided into two as follows: 
1.1 Actors in the network try to connect with actors who make many connections, called Indegree.

1.2 Actors in the network were connected by actors who have many relationships called Outdegree

2 The ability to access information and how far the information can be spread in the network. The degree of how the actor is close to other network members called Closeness centrality.

3 How far an actor is located or as a liaison among other actors in the network called Betweenness.

\section{Results and Discussion}

Identification of stakeholders Stakeholders are defined as groups, individuals, or institutions that have attention and/or influence the outcome of an activity (Kusumedi and Bisjoe 2010). It can be concluded that stakeholders are all parties both individually and in groups that can be influenced and/or influence the decision-making and achieve the objectives of an activity. Some stakeholders have a strong influence on the existence of various projects and should be considered as key stakeholders. While there are affected stakeholders and even they can influence the results and intervene in the proposed project. This is commonly seen in any natural resource management project, legally authorized managers always occupy positions as key stakeholders (Sembiring et al. 2010). It is, therefore, important to know which of the stakeholders are interested in participating or opposing the existence of the project so that it can lead to a conflict. Tensions between conflict and cooperation are inherent in the network because stakeholders want to increase their benefits (Ramos et al. 2013). Each stakeholder has different interests, needs, and perspectives, so the best way to resolve the conflict is to engage in the dialogue with various interest groups early in the project. By ensuring that identified stakeholders can represent the interests of those who cannot be directly involved. Analysis can help in identifying potential conflicts between actors at the beginning of the project stage. Thus, the problem can be identified and managed properly based on the consideration of the position of interests and influence that is owned by the stakeholders so that the goals to be achieved can be realized. This understanding can then be used to design and implement communication strategies between the parties.

Interviews, literature studies and field observations identified several main, key and supporter groups. There are 26 stakeholders involved in the management of mangrove institutions, as presented in Table 1.

The result of stakeholder identification show that the diversity of stakeholders involved in community-based mangrove management in FMU region 3 has different interests that will have consequences on management complexity. Hence an institution is required to regulate and influence the high level of importance to realize mangrove sustainability, forest management. FMU Region 3 as a site manager should be able to take a significant role and be able to work with other stakeholders and be able to manage potential conflicts that come from different interests. Differences of interests and influence among actors can be the source of conflict in the management of a region because each actor seeks to harness the power he has to get his interests (Febriyano 2014).
Stakeholder Mapping Stakeholder mapping is very useful to see the extent to which potential stakeholders will influence the project and/or results. So that their interests and interests can be seen, their readiness or priority in the project, if they are not involved, they will become opponents of the project. By ensuring their position on the grid can be seen how much power they have and how much interest they have in it.

There are four categories of stakeholder categories (Reed et al.2009) consisting of:

1 Subject

From the analysis result, it is known that Forest Management Agency (FMA) XVIII and Mangrove Forest Management Center Region are classified as Subject. Both institutions are government technical institutions that run programs which have been planned by the government. FMA XVIII is an institution that facilitates Forest Management Unit (FMU) in the form of forest boundaries, forest resource inventory, forest management planning and management, provision of facilities and infrastructure and coordination with provincial forestry services. The low influence of FMA is due to the extent of governance, not supported by the availability of adequate human and budgetary resources so that the planning of each program is based on the allocation of available funds and programs executed on a priority scale. While FMU Region 3 has a high interest because as a provider of forest management at the site level, it must ensure that forest management is carried out continuously in accordance with its function. Meanwhile, the effect is low because when the research is done, the organizational structure has not yet formed the lower level (Part of the Forest Management Unit and Forest Management Resort) and this institution is still newly formed. Empowerment strategy can be done that is institutional strengthening, technical competence, and representation in fulfillment process criteria and the indicator of the FMU region (Karsudi et al. 2010).

Local government agencies such as Department of Forestry and Estate Crops of Aceh Tamiang , Department Maritime, Fisheries and Agriculture of Langsa, Department of Forestry and Estate of East Aceh, Department of Maritime and Fisheries Affairs of Aceh Tamiang, Department of Maritime and Fisheries Affairs of East Aceh, r Department of Tourism of Langsa, Regional Development Planning Agency of Aceh Tamiang, Regional Development Planning Agency of Langs and Regional Development Planning Agency of East Aceh have high interests but low influence. Low influence is due to the absence or lack of program planning activities directed at mangrove management, while the position of NGOs Lembah Tari and NGO Bale Jurong is also as subject. The influence of NGOs is still low because this is not fully able to influence local government policy and advocate the community related to mangrove management policy. The involvement of universities has indirectly been instrumental in research and advocacy activities although the influence has not been so great. This is due to the lack of attention given to mangrove management.

Similarly, the Pusong Kapal Village community, 
Table 1 Stakeholders in mangrove management

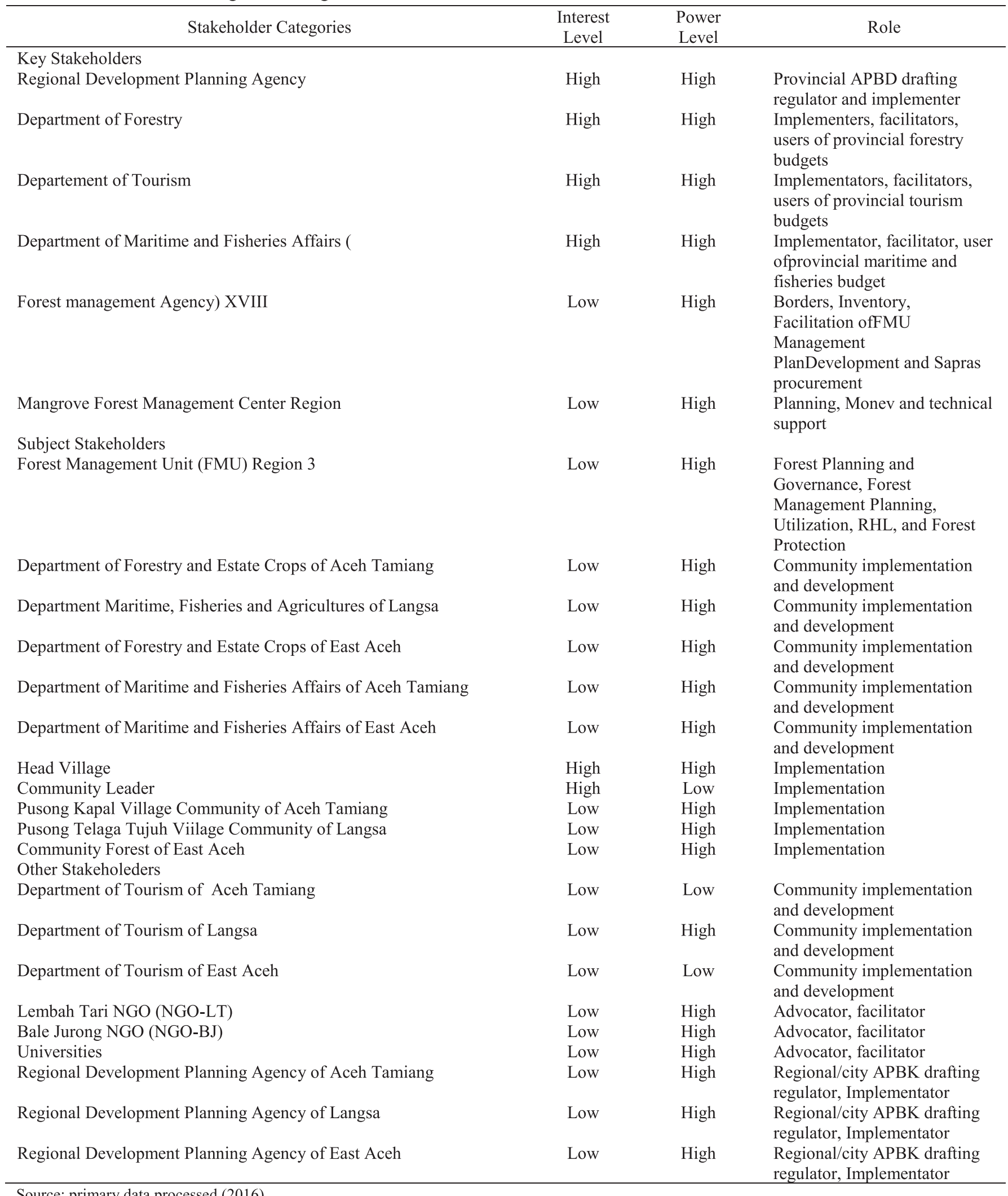

Pusong Telaga Tujoh Village community, and community forestry of East Aceh are covered in this category. Several research findings on previous stakeholders, Herawati et al. (2010) related to community forest plantation management; Kusumedi and Bisjoe (2010) on the development of the model FMU in Maros, which puts the people in the subject quadrant. In this context, the magnitude of the community's interest 
in mangrove resources is primarily concerned with improving their living standards, despite its low influence. This is due to the low capacity of society (limited knowledge, skills, and finances) and the frequency of society is only positioned as an object. Therefore, the process of community empowerment is needed through counseling and involving the community at every stage of management (Soetomo 2011). Such conditions will have significant influence through the formation of groups or alliances with other institutions or organizations. This alliance can be utilized to support the changes or progress that the institution or organization wants to achieve

\section{Key players}

Results of interest and influence matrices are known that Regional Development Planning Agency, provincial forestry offices, provincial tourism offices, and provincial maritime and fishery agencies are the key players. This is due to these government agencies as regulators, facilitators, implementers, and evaluators who are very influential on mangrove management policy. As a regulator, this would require input from other stakeholders involved to make effective decisions. The effectiveness of decision making is an integral part of the project (McIntyre 2008). Structurally this institution has a force of force and has a network of forces and cooperation at the level below it. So the institution that occupies this position (key players) is the actor who has a very important role and high influence in an institution. Several program activities of these institutions are directed to improve the management of mangrove forests. For example, the Forestry Service that makes the cooperation of mangrove forest management with the community of Pusong Kapal Village in Aceh Tamiang, Tourism Department through the development of tourism in mangrove forest in Langsa City, Marine and Fisheries Department through mangrove planting activities of 200 hectares in Aceh Tamiang and rehabilitation of mangrove ecosystem area in East Aceh. The most crucial issue is the availability of an adequate and sustainable budget allocation dedicated to the management of this mangrove. Thus, it often happens that the program activities only for one period budget only.

3 Context setter

Head village and community leader in context setter positions have high power as both of them have the ability to influence decisions related to resource management then legitimize it, and the ability to influence the community in joint action in mangrove management. Village heads and community leaders are in positions context setters that have a high influence as both can influence a choice of decisions related to resource management and then legitimize it and the ability to influence the community in joint action in mangrove forest management. Village heads and community leaders are symbolic power figures who have charisma and as role models for communities capable of initiating and mobilizing collective action in resource management (Suharti 2016).

4 Crowd

The tourism office of Aceh Tamiang and the East
Aceh tourism office are included in the Crowd category since both institutions did not place mangrove forests as their program of activity reflected in the district budget so that special interest and influence on mangrove management was lower than those from other stakeholders. However, these two institutions need to be considered to be involved as they can form an alliance with other group members to support change for the progress of the institution or organization.

From stakeholder mapping, it is clear that many of the stakeholders have their own mangrove management objectives. If only FMU can take on a larger role and become leaders in mangrove management at the site level, then there will be a common agenda and targets of the stakeholders involved to create a high level of success as a more effective mangrove management effort, involving stakeholders at the organizational level to organize agendas and common goals. This shows that in realizing the successful management of mangrove forests will not be separated from the role and participation of stakeholders who have influence and have an important position of various activities in the management of mangrove forests.

From the mapping of stakeholders, it is clear that many stakeholders have their own objectives of mangrove management. If the FMU can take a more significant role and become a leader in mangrove management at the site level related to coordination and unify the perception as an effort in mangrove management to be more effective. This action through the involvement of stakeholders at the organizational level to organize common agendas and targets. Related relationships among stakeholders as reported by Santoso et al. (2015) on tourism governance in Bunaken National Park, North Sulawesi that is so that activities run effectively coordinated so that the implementation does not happen overlap.

Inter-stakeholder network in mangrove management. The relationships of actors in the network provide information about how the network as a whole operates and assess the extent to which the network is focused on one or more nodes (nodes representing actors in the network). Cooperation in the network implies the mobilization of actors. Mobilization occurs when actors get shared vision and goals and have a strong commitment to each other (Ritvala and Salmi 2008). This approach highlights interorganizational relationships and provides a framework for analyzing how to build and maintain long-term relationships (Baraldi et al.2014). The results of social network analysis of actors are presented in Table 2.

The importance of the actor's position within the network greatly determines a node on a network. This can indicate whether the actor has a degree of proximity, hostility or prestige. This is important in the effectiveness and fluency of communicating; therefore, this shows how actors have influence and power in networking. If successful, it reinforces mutual commitment, reliance and relationship value. In this sense, relationships will affect actor actions and their behavior. It depends not only on direct interaction but also their perceptions of the value of a relationship, trust, and commitment among actors (Hakansson and Snehota 2006). It could be an actor who has high ability in mangrove management. However, because the actor is not connected in the network, then he has no significant role. One of the most 
Table 2 Centrality value relations between actors

\begin{tabular}{|c|c|c|c|c|c|}
\hline Actors & Indegree & Outdegree & Incloseness & Outcloseness & Betweeness \\
\hline FMU Region 3 & 58.000 & 71.000 & 58.140 & 27.174 & 73.607 \\
\hline Universities & 0.000 & 67.000 & 3.846 & 40.984 & 0.000 \\
\hline Department of Forestry & 63.000 & 42.000 & 62.500 & 24.038 & 36.098 \\
\hline Head Village & 83.000 & 41.000 & 75.758 & 26.882 & 152.117 \\
\hline Community Leader & 51.000 & 38.000 & 60.976 & 27.473 & 99.379 \\
\hline Pusong Kapal Village Community & 48.000 & 33.000 & 56.818 & 24.752 & 14.845 \\
\hline Regional Development Planning Agency & 40.000 & 32.000 & 46.296 & 23.810 & 50.729 \\
\hline $\begin{array}{l}\text { Department of Forestry and Estate Crops of } \\
\text { Aceh Tamiang }\end{array}$ & 30.000 & 31.000 & 55.556 & 25.000 & 79.250 \\
\hline $\begin{array}{l}\text { Department of Forestry and Estate Crops of } \\
\text { East Aceh }\end{array}$ & 27.000 & 29.000 & 50.000 & 26.316 & 95.636 \\
\hline $\begin{array}{l}\text { Department Maritime, Fisheries and } \\
\text { Agricultures of Langsa }\end{array}$ & 26.000 & 23.000 & 49.020 & 24.038 & 26.829 \\
\hline Forest management Agency XVIII & 17.000 & 22.000 & 40.323 & 22.936 & 0.000 \\
\hline $\begin{array}{l}\text { Mangrove Forest Management } \text { Center } \\
\text { Region }\end{array}$ & 5.000 & 17.000 & 40.323 & 23.364 & 0.000 \\
\hline Pusong Telaga Tujoh Village Community & 17.000 & 17.000 & 48.077 & 22.936 & 1.117 \\
\hline NGO Lembah Tari & 2.000 & 17.000 & 36.232 & 24.727 & 0.000 \\
\hline $\begin{array}{l}\text { Department of Maritime and Fisheries } \\
\text { Affairs of Aceh Tamiang }\end{array}$ & 17.000 & 15.000 & 48.077 & 23.364 & 29.331 \\
\hline $\begin{array}{l}\text { Department of Maritime and Fisheries } \\
\text { Affairs }\end{array}$ & 22.000 & 13.000 & 44.643 & 21.008 & 11.002 \\
\hline $\begin{array}{l}\text { Regional Development Planning Agency of } \\
\text { Langsa }\end{array}$ & 7.000 & 13.000 & 29.070 & 23.810 & 5.133 \\
\hline Forest Community & 21.000 & 13.000 & 49.020 & 24.752 & 0.143 \\
\hline Departement of Tourism & 18.000 & 13.000 & 35.211 & 20.833 & 13.690 \\
\hline $\begin{array}{l}\text { Regional Development Planning Agency of } \\
\text { East Aceh }\end{array}$ & 16.000 & 13.000 & 35.714 & 23.810 & 28.833 \\
\hline $\begin{array}{l}\text { Department of Maritime and Fisheries } \\
\text { Affairs of East Aceh }\end{array}$ & 9.000 & 12.000 & 40.984 & 23.364 & 7.700 \\
\hline NGO Bale Jurong & 2.000 & 12.000 & 34.722 & 21.930 & 33.210 \\
\hline Department of Tourism of Langsa & 11.000 & 10.000 & 31.250 & 23.585 & 18.367 \\
\hline $\begin{array}{l}\text { Regional Development Planning Agency of } \\
\text { Aceh Tamiang }\end{array}$ & 16.000 & 6.000 & 39.683 & 21.186 & 24.986 \\
\hline Department of Tourism of East Aceh & 3.000 & 6.000 & 26.596 & 22.727 & 0.000 \\
\hline Department of Tourism of Aceh Tamiang & 0.000 & 3.000 & 3.846 & 21.552 & 0.000 \\
\hline
\end{tabular}

Source: Primary data procssed (2016)

important factors to succeed or not in the management of mangroves lies in the support or rejection of the actors involved. Therefore, there is always a need to increase trust in commitment. The result of representation of the relationship among actors in mangrove management network can be seen in Figure 1.

Some groups are formed in the network, but there are also actors who move away from other networks. On the network, there are some actors who have a significant role in the network. An actor who has a significant role if he has a good centrality size will usually form a subgroup on the existing network. The degree of centrality of mangrove forest management information network is presented in Figure 2.

Figure 2 shows four actors with the highest level of 


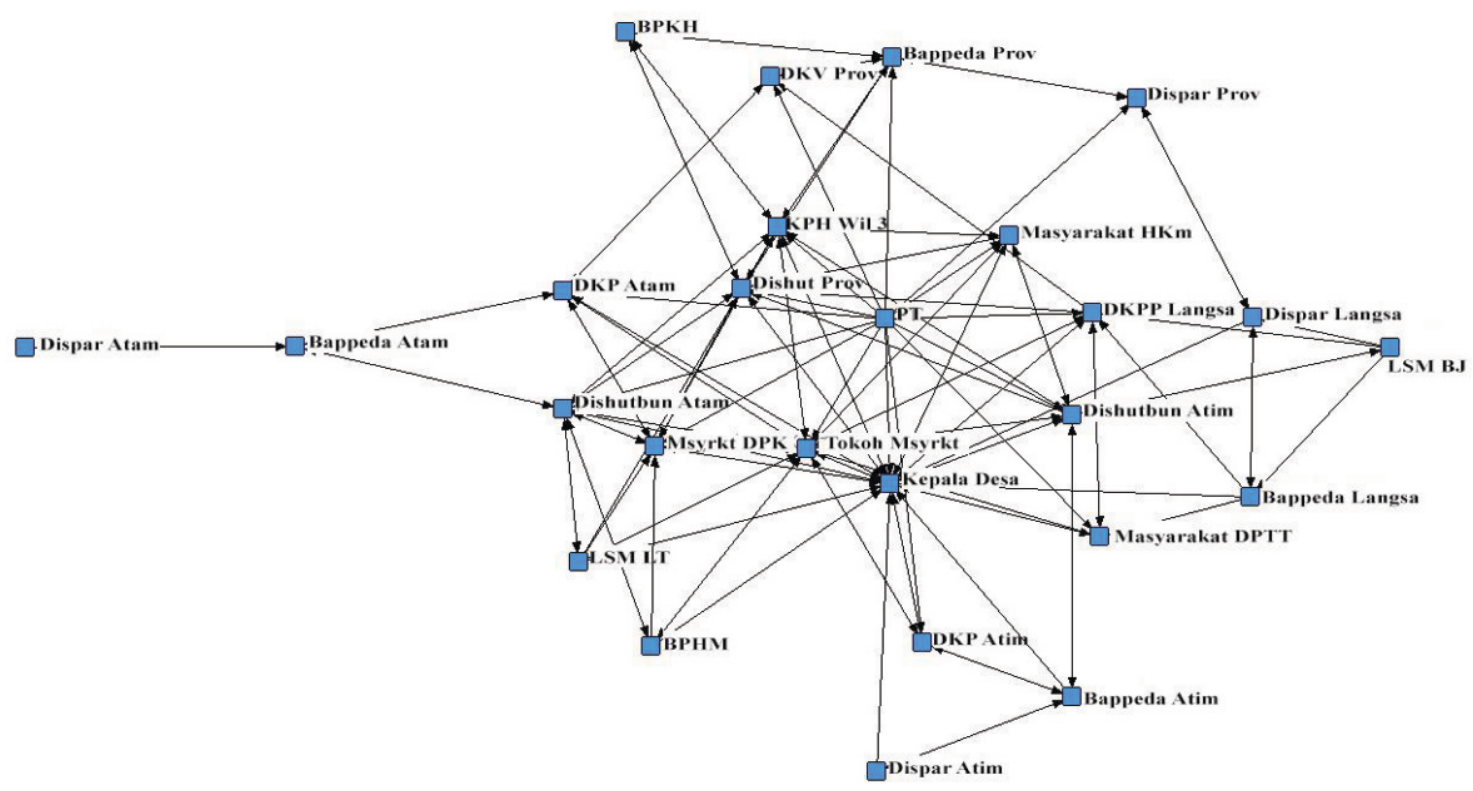

Figure 1 Representation of relationships among actors in the network.

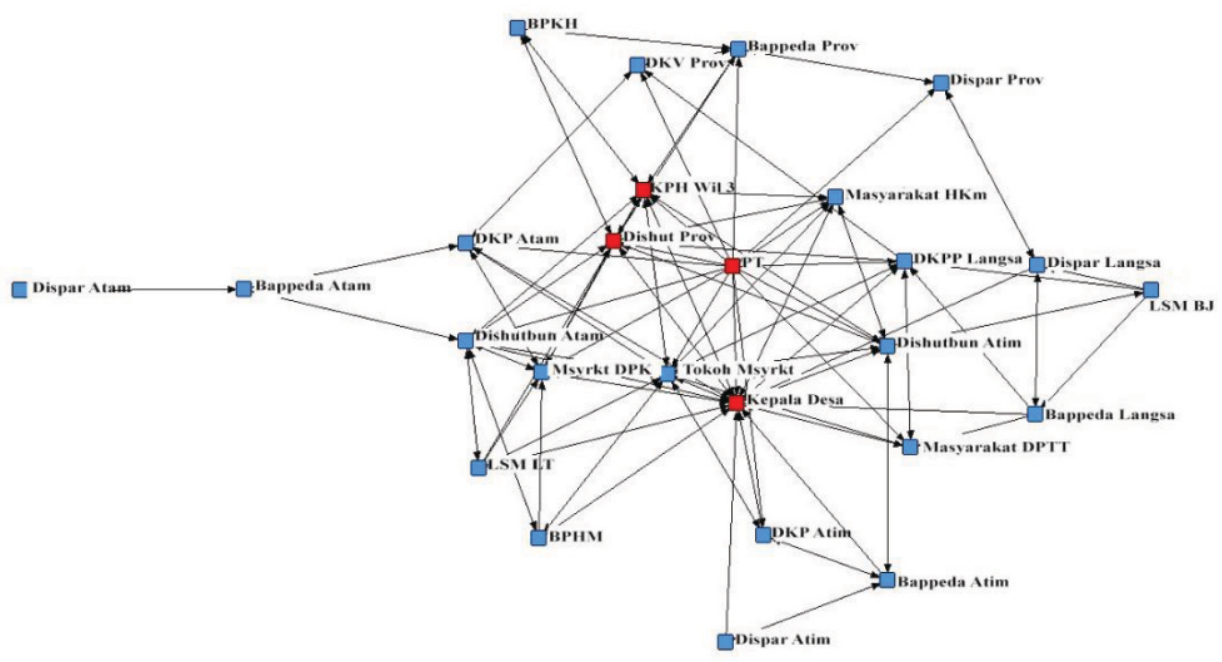

Figure 2 Degree centrality of mangrove management actors information network. Highest SNA value ( $\square$ ), The lowest SNA value ( $\square$ ).

information connectivity, i.e. Village Head, Provincial planning and development agency, Provincial forestry service, FMU, and University. Information connectivity is the sum of information levels and degrees. The level of connectivity is a way of identifying actors as opinion leaders, in which they often contact actors as a major source of support within the network. While the smallest is Department of tourism of Aceh Tamiang, which means almost isolated from the mangrove management information traffic. In Table 2, it appears that for the indegree criteria the actors with the highest scores are the Village Head, provincial forestry service, and FMU. The existence of each interaction is 83,63 , and 58 actors. While FMU, provincial forestry service, and University interacted as many as 71, 67,42 to other actors (outdegree).

There are three actors in the network that have the highest value of the centrality of proximity, as shown in Table 2. The highest values are in the order of the Village Head, Provincial forestry service, and Community Leaders with the respective values of $75,758,62,500,60,976$. This implies that the village head, provincial forestry service, and the Community Leaders have a closeness with the parties so that they are better able to communicate with other actors, as shown in Figure 3. 


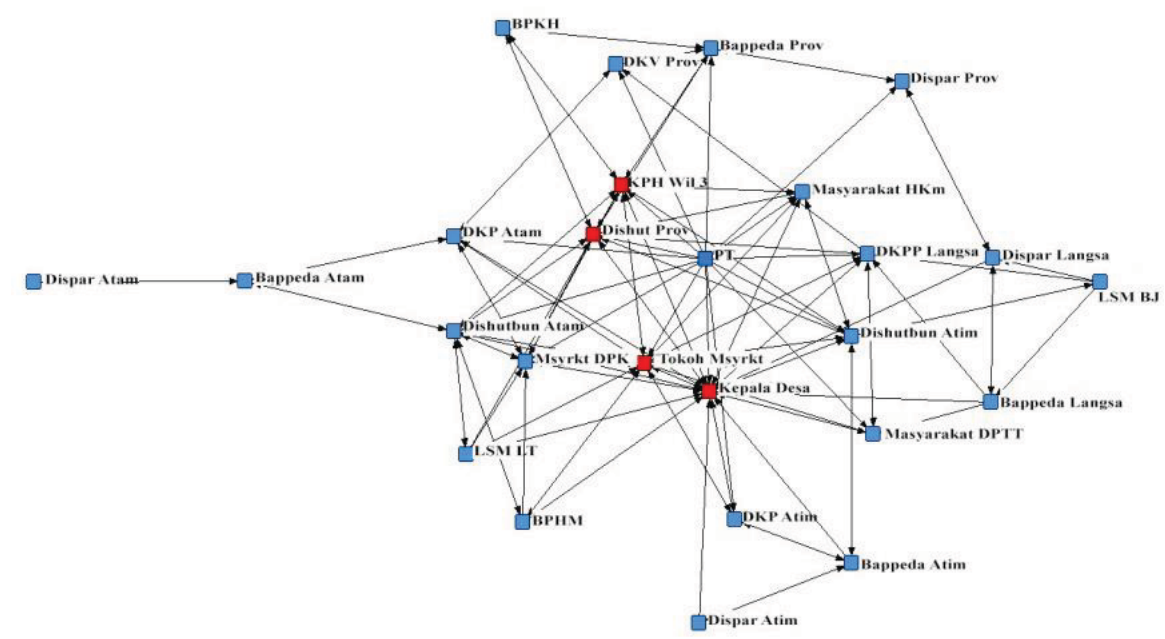

Figure 3 Closeness centrality of mangrove management actors information network. Highest SNA value ( $\square$ ), The lowest SNA value $(\square)$.

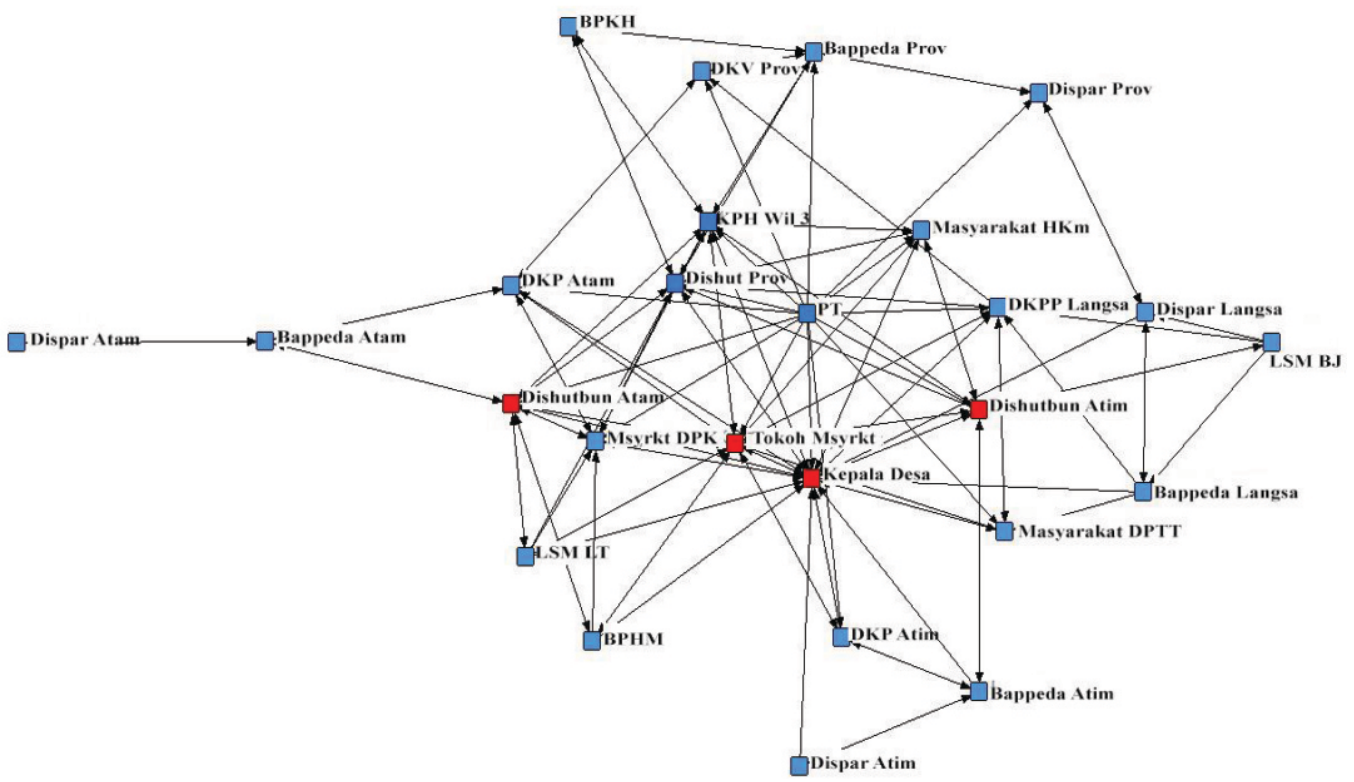

Figure 4 Betweenness of mangrove management actors information network. Highest SNA value ( $\square)$, The lowest SNA value ( ).

Figure 3 shows that based on the value of in closeness centrality, the three actors have a high value indicating that the actors have a close relationship with the maximum of other actors. The actor has the highest in closeness centrality value because the actor has quick access to other actors and certainly has high visibility to know what is going on in the network. While the highest out closeness value is the university, Community Leaders, and FMU without closeness of $40,984,27,473$, and 27,174 , this shows the ability of the three actors to convey information to other actors in the network related to mangrove management. The continuous exchange of information over time is essential to create and develop relationships and reduce uncertainty, leading to the development of services between actors based on cooperation and trust (Hakansson and Ford 2002). The role of actors in bridging information between two other actors is shown in Figure 4.

An important role of actors in bridging the information between the two other actors is shown in Figure 4. Village Heads, Community Leaders, Department of forestry and estate crops of East Aceh, and Department of forestry and crops of Aceh Tamiang are the four most important figures in bridging the information network of mangrove forest management. From Table 2, it shows that four actors have the 
highest intermediate values, in which each has values of 152.117, 99.379, 95.636, and 79.250. Thus the four can connect other actors in the network. The actor who has the highest intermediate betweenness value is indeed occupying the most important position or the most powerful in the network.

\section{Conclusion}

Mapping of stakeholders is done to determine the position or position of each stakeholder with different levels of interests and their influence and contribution especially in planning and formulating integratively mangrove management as a common goal. From the results of this mapping, FMU as a manager organization at the tread level has not seen its role in efforts to increase its interests and influence. The emergence of several actors such as Pusong Kapal Village community, Pusong Telaga Tujoh Village community, community forest, the village head, and community leaders provide an indication of how to manage through the support of mechanisms, and the growing aspirations of the stakeholders when formulating and designing stronger strategies. This is a matter of consideration to encourage support to stakeholders in building coalitions. Managing stakeholders is not merely putting them at the level of importance and influence in mangrove management, but how FMU can develop management strategies by revealing more about the interests and influences that relate to their position of interaction in other stakeholder networks. From the analysis of the network can be identified who the stakeholders who have a great influence, either as opinion leaders, who have fast access or as an intermediary in the network. With this information, the FMU can build and maintain long-term relationships that involve interaction patterns especially with stakeholders having a major influence within the network. Over time, the longer the relationship is built, the more likely it is that interactions can become institutionalized because the connections developed among the parties that will result in a reciprocal relationship and commitment.

\section{Recommendations}

Village heads and community leaders are very influential actors in mangrove management. Therefore, these two actors should always be involved in any decision-making related to mangrove management, especially as a liaison within the network among other actors.

\section{Acknowledgement}

The authors extend deeply acknowledgment to the Ministry of Research, Technology and Higher Education, Directorate General of Science \& Technology Resource and Higher Education Indonesia for scholarship and support to fund and accomplish this research.

\section{References}

Baraldi E, Proença JF, Proença T, de Castro LM. 2014. The supplier's side of outsourcing: Taking over activities and blurring organizational boundaries. Industrial Marketing Management 43(4):553-563. https://doi.org/10.1016/ j.indmarman.2014.02.012
Barman-Adhikari A, Rice E, Winetrobe H, Petering R. 2015. Social network correlates of methsmphetamine, heroin, and cocaine use in a sociometric network of homeless youth. Journal of the Society for Social Work and Research 6:433-457. https://doi.org/10.1086/682709.

Borgatti SP, Everett MG, Freeman LC. 2002. Ucinet 6 for Windows: Software for Social Network Analysis. Harvard, MA: Analytic Technologies.

Borgatti SP, Everett MG, Johnson JC. 2013. Analyzing Social Networks. London: SAGE Publications.

Brekke JS. 2012. Shaping a science of social work. Research on social work practice 22:455-464. https://doi.org/ $10.1177 / 1049731512441263$.

Bungin B. 2010. Penelitian Kualitatif. Jakarta: Kencana Prenada Media Group.

Bunger AC, Doogan NJ, Cao Y. 2014. Building service delivery networks: Partnership evolution among children's behavioral health agencies in responese to new funding. Journal of the Society for Social Network and Research 5(4):513-538. https:// doi.org/10.1086/679224.

Crossley N. 2010. The social world of the network. Combining qualitative and quantitative elements in social network analysis. Sosiologica 4.

Febriyano IG. 2014. Politik ekologi pengelolaan mangrove di Kabupaten Pesawaran Provinsi Lampung [dissertation]. Bogor: Bogor Agricultural University.

Fletcher A, Guthrie J, Steane P, Ross G, Pike S. 2003. Mapping stakeholder perception for a third sector organization. Journal of Intellectual Capital 4(4):505-527. https://doi.org/10.1108/14691930310504536.

Håkansson H, Ford D. 2002. How should companies interact in business networks? Journal of Business Research 55(2):133-139. https://doi.org/10.1016/S01482963(00)00148-X.

Håkansson H, Snehota I. 2006. No business is an island: The network concept of business strategy. Scandinavian Journal of Management 22(3):256-270. https://doi.org/10. 1016/j.scaman.2006.10.005.

Henwood BF, Stefanic A, Petering R, Schreiber S, Abrams C, Padgett DK. 2015. Social relationships of dually diagnosed homeless adults following enrollment in housing first or traditional treatment service. Journal of the Society for Social Work and Research 6(3):385-406. https://doi.org/10.1086/682583.

Herawati T, Widjayanto N, Saharuddin, Eriyatno. 2010. Analisa respon pemangku kepentingan di daerah terhadap kebijakan hutan tanaman rakyat. Jurnal Analisis Kebijakan Kehutanan 7(1):13-25. https://doi.org/10. 20886/jakk.2010.7.1.13-25.

Hollstein B. 2011. Qualitative approaches. In: The Sage 
Handbook of Social Network Analysis; Scott J, Carrington PJ, editors. SAGE Publications Ltd. Cornwall, United Kingdom.

Kadushin C. 2012. Understanding Social Networks: Theories, Concept and Finding. New York: Oxford University Press.

Karsudi, Soekmadi R., Kartodihardjo H. 2010. Model pengembangan kelembagaan pembentukan wilayah kesatuan pengelolaan hutan di Provinsi Papua. Jurnal Manajemen Hutan Tropika 16(2):92-100.

Kartodihardjo H. 2011. Penanganan konflik kehutanan: Peran dan pengalaman Dewan Kehutanan Nasional. Forum DKN untuk Mediasi Konflik. Kongres Kehutanan Indonesia (KKI) ke-V, Jakarta 21-24 November 2011.

Kusumedi P, Bisjoe ARH. 2010. Analsis stakeholder dan kebijakan pembangunan FMU Model Maros di Propinsi Sulawesi Selatan. Jurnal Analisis Kebijakan Kehutanan 7(3):179-193.

McIntyre A. 2008. Participatory Action Research. California: Sage Publications.

Muntasib EKSH. 2014. Mechanism of stakeholder relationship in nature tourism management in Indonesia. TEAMJournal of Hospitality and Tourism 11(1):81-92.

Race D, Millar J. 2008. Social and Community Dimensions to ACIAR Project. (ACIAR Training Manual). Australian Centre for International Agricultural Research Canberra: Charles Sturt University.

Ramos C, Roseira C, Brito C, Henneberg SC, Naude P. 2013. Business service networks and their process of emergence: The case of the health cluster Portugal. Industrial Marketing Management 42(6):950-968. https://doi.org/ 10.1016/j.indmarman.2013.04.003.

Rastogi A, Badola R, Haussain SA, Hickey GM. 2010. Assessing the utility of stakeholder analysis to protected areas management: The case of Corbett National Park, India. Biological Conservation 143(12):2956-2964. https://doi.org/10.1016/j.biocon.2010.04.039.

Reed SM, Graves A, Dandy N, Posthumus H, Huback K, Morris J, Prell CH, Quin CH, Stringer LC. 2009. Who's in and why? A typology of stakeholder analysis methode for natural resources management. Journal of Environmental Management 90(5): 1933-1949. https://doi.org/10.1016/ j.jenvman.2009.01.001.

Ritvala T, Salmi A. 2008. Actor mobilization and institutional change around a common issue: The case of fighting heart disease in Finland. Paper presented in 24th Industrial Marketing Puschasing Conference, Uppsala, Sweden.

Santoso H, Muntasib EKSH, Kartodihardjo H, Soekmadi R. 2015. Peranan dan kebutuhan pemangku kepentingan dalam tata kelola pariwisata di Taman Nasional Bunaken Sulawesi Utara. Jurnal Penelitian Sosial dan Ekonomi Kehutanan 12(3):197-211.

Saz-Carranza A, Ospina S. M. 2010. The behavioral dimension of governing interorganizational goal-directed networks-managing the unity-diversity tension. Journal of Public Administration Research and Theory 21(2):327-365. https://doi.org/10.1093/jopart/muq050.

Sembiring E, Basuni S, Soekmadi R. 2010. Resolusi konflik pengelolaan Taman Nasional Teluk Cendrawasih di Kabupaten Teluk Wondama. Jurnal Manajemen Hutan Tropika 16(2):84-91.

Scott J. 2011. Social Network Analysis. Theory and Application. London: SAGE Publication.

Soetomo. 2011. Pemberdayaan Masyarakat: Mungkinkah Muncul Anti Tesisnya. Yogyakarta: Pustaka Pelajar.

Suharti S. 2016. Kemandirian pengelolaan sumberdaya mangrove melalui penguatan modal sosial masyarakat: Pembelajaran dari Sinjai Timur Sulawesi Selatan. [disertasi]. Bogor: Bogor Agricultural University.

Soontornwong S. 2006. Improving livelihood through CBNRM: A case of self-organization in community mangrove management in Thailand. In: Mahanty S, Fox J, Nurse M, Stephen P, McLees L, editors. Hanging in the balance: equity in community-based natural resource management in Asia. East-West Center, Honolulu, Hawaii, USA. pp 182-199.

Stanton NA, Walker GH, Sorensen LJ. 2012. It's a small world after all: Contrasting hierarchical and edge networks in a simulated intelligence analysis task. Ergonomics 55:265-281. http://doi.org/10.1080/00140139. 2011.642006 .

Thompson R. 2011. Stakeholder analysis. Winning support for your project. http://www.mindtools.com/pages/article/ newPPM_07.htm. [23 October 2015]

Yami M, Vogl C, Hauser M. 2011. Informal institutions as mechanisms to address challenges in communal grazing land management in Tigray, Ethiopia. International Journal Sustainable Development World Ecology 18(1):78-87. https://doi.org/10.1080/13504509. 2010.530124 . 